adequate anticonvulsant treatment should raise the possibility of pseudostatus epilepticus.

The correct diagnosis was not made in these five patients for several reasons. Four patients had been diagnosed incorrectly as probable or definite epilepsy. These diagnoses prejudiced the true diagnosis when they were admitted. Lack of familiarity with real seizures contributed since all patients clearly had non-organic seizures when witnessed by medical staff. None of the patients had bitten their tongue or been incontinent despite frequent apparent grand-mal seizures. Most often the so-called seizures consisted of opisthotonos with alternate flapping of the limbs and twisting of the head from side to side. Patients responded to pain or commands during the seizures and there was no colour change. The sequence of events was identical in every patient. An isolated seizure initially led to admission to hospital. Further seizures subsequently occurred on the ward and were treated with diazepam. Seizures then became increasingly frequent despite increasing doses of anticonvulsant drugs, culminating in what seemed to be status epilepticus. None of the patients were in status epilepticus on admission. Electroencephalographic changes of minor abnormality were sometimes interpreted as supporting a diagnosis of epilepsy. Lack of availability of continuous monitoring made diagnosis difficult but in no patient was pseudoseizure suspected. Two of the five patients had psychiatric problems and one had a clear emotional precipitant of the pseudostatus epilepticus. By the time of transfer to the centre all patients were severely sedated by their medication and one had previously been in intensive care because of respiratory depression due to chlormethiazole.

It is thus unwise to diagnose epilepsy if in doubt since once the label is acquired it is difficult to lose. A trial of anticonvulsant treatment is rarely useful in establishing the diagnosis of epilepsy and can lead to unnecessary long-term treatment, as has happened in two of our patients. Increasingly frequent serial seizures after admission despite adequate anticonvulsant treatment should raise the possiblity of pseudostatus epilepticus.

Wessex Neurological Centre,

Southampton General Hospital,

Southampton Goneral $\mathrm{XY}$

D. E. BATEMAN

1. Howell SJL, Owen L, Chadwick DW. Pseudostatus epilepticus. $Q \mathcal{F}$ Med 1989; 266: 507-19.

\section{BRAIN MUSCARINIC RECEPTORS IN ALZHEIMER'S AND PARKINSON'S DISEASES}

SIR,-Dementia without substantial Alzheimer-type changes in the cerebral cortex is sometimes seen in patients with Parkinson's disease. ${ }^{1}$ Subcortico-cortical cholinergic alterations are features of both Alzheimer's disease (AD) and Parkinson's disease (PD) ${ }^{2,3}$ Neuronal loss in the nucleus basalis of Meynert is observed ${ }^{1,4}$ and reductions in cortical choline acetyltransferase (CAT) activity correlate with the degree of dementia in both diseases. ${ }^{1,5,6}$ The status of muscarinic cholinergic receptors is less clear. We have looked at CAT activity and muscarinic receptor binding in the temporal cortex (Brodman area 38) and hippocampus in neuropathologically confirmed $\mathrm{AD}$ and PD.

Brain was obtained at necropsy from nine patients with $\mathrm{AD}$ and from nine matched controls with no evidence of neurological or psychiatric diseases and from nine patients with PD (four with dementia) and nine matched controls. The demented patients had profound progressive disturbances in memory and cognitive impairment. The parkinsonian patients had been on levodopa at the time of death and two had also received anticholinergic medication. Neither the patients with $\mathrm{AD}$ nor the controls had received any drug known to affect the central nervous system. Using membrane homogenates we did saturation analyses for total muscarinic receptors with $\left[{ }^{3} \mathrm{H}\right]$-quinuclidinylbenzilate $(\mathrm{QNB})$ and for type 1 (M-1) receptors with $\left[{ }^{3} \mathrm{H}\right]$-pirenzepine. Non-specific binding was defined by atropine. Protein concentrations and enzyme activities were measured by standard techniques (details from K. W. L.).
MEAN (SEM) MAXIMAL RECEPTOR BINDING IN CORTEX AND HIPPOCAMPUS

\begin{tabular}{|c|c|c|c|c|}
\hline - & $\begin{array}{l}\text { Control } \\
(n=9)\end{array}$ & $\begin{array}{c}\mathrm{AD} \\
(\mathbf{n}=9)\end{array}$ & $\begin{array}{l}\text { Control } \\
(\mathbf{n}=9)\end{array}$ & $\begin{array}{c}\text { PD } \\
(\mathbf{n}=9)\end{array}$ \\
\hline $\begin{array}{l}\text { Age (yr) } \\
\text { Death to brain }\end{array}$ & $83 \cdot 7(2 \cdot 3)$ & $80 \cdot 4(2 \cdot 5)$ & $74 \cdot 3(3 \cdot 9)$ & $73 \cdot 1(2 \cdot 6)$ \\
\hline $\begin{array}{l}\text { removal }(h) \\
C A T \text { activity }\end{array}$ & $39 \cdot 3(2 \cdot 3)$ & $38 \cdot 8(6 \cdot 5)$ & $19 \cdot 6(2 \cdot 7)$ & $18 \cdot 1(3 \cdot 0)$ \\
\hline Temporal cortex & $4 \cdot 3(0 \cdot 3$ & $1 \cdot 1(0 \cdot 1)^{\star}$ & $4 \cdot 4(0 \cdot 2)$ & $2 \cdot 4(0 \cdot 3)^{\star}$ \\
\hline $\begin{array}{l}\text { Hippocampus } \\
{ }^{3} H_{-}^{-}-Q N B \text { binding }\end{array}$ & $12 \cdot 4(0 \cdot 9)$ & $2.6(0.4)^{\star}$ & $13 \cdot 0(1 \cdot 1)$ & $5.5(1.0)^{\star}$ \\
\hline Temporal cortex & $814(30)$ & $802(33)$ & $844(24)$ & $952(13)^{\star}$ \\
\hline $\begin{array}{l}\text { Hippocampus } \\
{ }^{3} H \text {-pirenzepine binding }\end{array}$ & $361(15)$ & $298(14)^{\star}$ & $336(18)$ & $358(23)$ \\
\hline Temporal cortex & & $590(16)$ & $659(19)$ & $755(10)^{\star}$ \\
\hline Hippocampus & $241(17)$ & $224(16)$ & $215(17)$ & $220(13)$ \\
\hline
\end{tabular}

Wilcoxon's rank-sum test: ${ }^{\star} \mathrm{p}<005$.

CAT activity in nmol $/ \mathrm{h} / \mathrm{mg}$ protein; $\mathrm{QNB}$ and pirenzepine binding as $\mathrm{B}_{\max }$ in fmol $/ \mathrm{mg}$ proten.

CAT activity was much reduced in both cortex and hippocampus in $A D$ and in PD (table). Muscarinic receptors were differently affected in the two diseases. Patients with AD showed no change in temporal cortex concentrations of total muscarinic receptors and $\mathrm{M}-1$ receptors; there was reduced $\left[{ }^{3} \mathrm{H}\right]-\mathrm{QNB}$ binding and unchanged $\left[{ }^{3} \mathrm{H}\right]$-pirenzepine binding in the hippocampus. By contrast, demented and non-demented patients with PD had increased concentrations of both the total muscarinic receptors and M-1 receptors in the cortex and no alterations in hippocampal receptors. Altered $K_{D}$ values were not observed.

Different alterations of muscarinic receptors in $A D$ and $P D$ may reflect fundamental differences in the pathophysiological process underlying dementia in these diseases. Increased concentrations of cortical muscarinic receptors may represent a compensatory mechanism which can maintain normal cognitive function in PD during the early stages of altered cholinergic transmission. ${ }^{7}$ Despite extensive CAT loss in $\mathrm{AD}$ and $\mathrm{PD}$, muscarinic receptor alterations are far less striking and retain the potential for pharmacological replacement therapy of the cholinergic deficit.

Supported by the Medical Research Council, the Parkinson's Disease Society, and the Research Funds of the Bethlem Royal and Maudsley Hospitals and King's College Hospital. K. W. L. was supported by the Deutsche Forschungsgemeinschaft. Brain tissue specimens were obtained from the Parkinson's Disease Society Brain Bank, London, and the MRC Brain Bank, Cambridge.

University Department of Neurology

and Parkinson's Disease Research Centre,

Institute of Psychiatry

and King's College School of Medicine,

London SE5 8AF;

Department of Neurology,

St Mary's Hospital,

London W2;

Department of Pharmacology,
King's College, University of London,

King's College, University of London,

London SW3;

and University Department of Clinical Neurology,

Institute of Neurology

and National Hospital

F. R. WELLS

M. N. RosSOR

London WCl

P. JENNER

C. D. MARSDEN

1. Perry EK, Curtis $M$, Dick DJ, et al. Cholinergic correlates of cognituve impairment in Parkinson's disease: comparison with Alzheimer's disease. $f$ Neurol Neurosurg Psychatry 1985; 48: 413-21

2. Rossor MN, Garrett NJ, Johnson AL, Mountjoy CQ, Roth M, Iversen LL. A post-mortem study of the cholmergic and GABA systems in senile dementia. Brain 1982; 105: 313-30.

3. Dubors $B$, Ruberg $M$, Javoy-Agd $F$, Ploska A, Agld $Y$ A subcortuco-cortical cholinergic system is affected in Parkinson's disease. Brain Res 1983; 288: 213-18.

4 Candy JM, Perry RH, Perry EK, et al. Pathological changes in the nucleus of Meynert in Alzheimer's and Parkinson's diseases. F Neurol Sol 1983; 59: 277-89.

5. Perry EK, Tomlinson BE, Blessed G, Bergmann K, Gibson PH, Perry RH. Correlation of cholinergic abnormalines with senule plaques and mental test scores in sentle dementia. $\mathrm{Br}$ Med 7 1978; ii 1457-59.

6. Ruberg M, Ploska A, Javoy-Agd F, Agid Y Muscannic binding and cholne acetyitransferase activity in Parkinsonian subjects with reference to dementia. Brain Res 1982; 232: 129-39.

7. Dubois B, Danze F, Pillon B, Cusimano G, Lhermirte F, Agıd Y. Cholinergicdependent cognitive defects in Parkinson's disease. Ann Neurol 1987, 22: 26-30. 